\title{
"Tess" and "Jude the Obscure". Examination of Hardy's Modernist Literary Spirit
}

\author{
Hui WANG \\ Humanistic and Foreign Language College \\ University of Science and Technology of Xian \\ Xi'an ,710054, China
}

\begin{abstract}
Thomas Hardy is not only an excellent successor of the British realism literary, but also a pioneer of modern literature. His novels have duality. On one hand, he inherited the great tradition of realism literary, profoundly expose many malpractices of Victoria dynasty; on the other hand, he also created a precedent for the British modernism, and painfully analyze the kind of dilemma plight in modern capitalist society. For example, his early novels depict life as full of poetic, but his late novels, mainly his tragic novel "Return of the Native," "The Mayor of Caster Bridge," "Tess" and "Jude the Obscure", have been shrouded in an atmosphere of pessimism. These tragic novels have a strong sense of crisis which is quite like modernism literature. Antisocial tendencies alienation and anxiety for the fate of mankind reflected in modern literature, is characterized by a series of tragic tone of these novels.
\end{abstract}

Keywords- Hardy; modernism; Literary Spirit

\section{INTRODUCTION}

Thomas Hardy, British Literature master in the counter of the 19th and the 20th Century, mainstream critics view has been defined Hardy as realism literary master, but do not pay much attention to his burgeoning modernist literary thought. This paper chooses two representative works of Thomas Hardy "Tess" and "Jude the Obscure" as the study object, from the human and moral division to analyze its contained modernist literary spirit light.

To better illustrate this article view, we must first understand what the ideological characteristic of modernist literature is. Scholar Yuan Kejia summed it up as follows: "In the four basic relations has shown overall distortion and serious alienation: the man and society, man and man, man and nature (including natural, human and material world) and people with self these four relations' sharp contradiction and deformity of touch, and the resulting trauma." One of the root causes of the ideological characteristic is Marx's alienation theory. About what is "alienation", the general understanding is that: "in the development process of the subject, due to their activities generate their own antithesis, then the opposite as an external alien force to dominate the body." It is this external force alienation oppress and tear down human, which leads to several factors which is original conducive to human development and in harmony with people went hostile with people on the opposite side. So we can say that alienation is the producer and external forces of such morbid division, separatist forces are applied to the results of this alienation caused by man, it is a causal relationship between the two.

\section{FROM THE "SPLIT" LOOK HARDY’S MODERNIST LITERARY THOUGHT}

To discuss this modernist literature thought contained in the two works, we must first understand what the ideological characteristic of modernist literature is, this will help us to better analyze the two works. Scholar Yuan Kejia summarized as "typical characteristics modernist ideological content is the four basic relations which demonstrated by the overall distortion and serious alienation: the man and society, man and man, man and nature (including the nature human nature and the material world) and the human with the self these four relations' sharp contradiction resulting trauma and abnormal psychology, the mood of pessimism and nihilism of thinking." the root causes of these ideological characteristic is also Marx's theory of alienation. Ehrlich Fromm once explained, "alienation reached similar psychotic proportions, it shakes spiritual and political traditions of the world religions; and predicts the risk of widespread destruction by nuclear war, because alienation has reached such an extent that more and more people recognize more clearly, sick people is the recognized modern major problem by Marx. "About what is 'alienation' "? Each has a different emphasis, the generally understanding of alienation: "in the development process of the subject, due to their activities generate their own antithesis, then the opposite as an external alien force to dominate the body." It is this external force alienation oppress and tear down human, which leads to several factors which is original conducive to human development and in harmony with people went hostile with people on the opposite side. So we can say that alienation is the producer and external forces of such morbid division, separatist forces are applied to the results of this alienation caused by man, it is a causal relationship between the two.

"Tess" and "Jude the Obscure" these two novels present the exceedingly acute and profound opposition, conflict, tears between human and the society. The power of social alienation of human oppression, strong distortions between man and society is precisely one of the topics thought of modernist literary performance. 


\section{HARDY's MODERNIST LITERATURE ART SKILLS}

One characteristics of modern literary art is the "inside" literature, emphasize subjective, consider that only people's intuition, that instinct can know the truth and the reality, oppose ration but promote using unspeakable inner experience to understand things, and feel the external material world can not be trusted, only one's heart is true, only recognize a feature called "psychological reality" as reality. The characteristics of this modernist literature art are built on modern psychological theory, and their representative is Floyd. We used to think that people's consciousness decide action, while the opposite is true, the action determine human consciousness. Modernist literature borrowed this theory that literature would like dreaming in general, because the dream is human instincts process, writers should seek this instinct truth, because this is the real existence. So modernist literary artistic expression extensively used dreams, hallucinations, intuitive instincts, morbid psychological (morbid and dreams like all reflect human instinct) description, modernist literature emphasizes linking the dream of free association with art imagine, then outstanding subconscious.

Although Freud's psychoanalytic theory formed after Hardy's "Tess" and "Jude the Obscure", but the distance of historical time is not far, and these two works have some link of dreams, hallucinations, and psychological description. It can also present Hardy is indeed lofty idea, keen perception that inherited literary tradition but also a great writer on practical innovation.

French philosopher Henri Bergson (1859-1941)'s life philosophy and theory of intuition "inside" modernist literature also have a profound impact on "inside". He believes that the impulse is the only real life, the life with life impulse is coming, you can not rely on reason and science to understand, only intuition can grasp life, percept unspeakable inner experience, intuition process is a process beyond ration.

\section{MODERN SPIRIT OF HARDY'S TRAGEDY NOVELS}

The life scope Hardy's tragic novel depicted is much less than his predecessors

Dickens, Thackeray and others, but Hardy shows us the background is transcended. In his view, the hero of the tragedy is not only a true portrayal of trauma of individual farmers were struggling hard process in the nineteenth century under the rule of law in rural areas, and world-weary attitude of human life from the previous joyful attitude towards pessimism history of the transition, his tragedy is not only Wessex customs, but also the explosion of the mankind fate. At this point, Hardy was unlike many other writers in the nineteenth century. Dickens's novels show a broad picture of life, but because he was limited to the issue of a person narrative, which did not put the fate of the hero linked with the fate of mankind, so the significance of his work is limited scope reformist, not out of traditional self-regulation social model, he wrote only general to the specific. George Eliot who just likes Thomas Hardy was trying to write specific in general, but his lengthy sermons make her work as the struggle between good and evil which is weakened, rather than anxiety for the fate of mankind and exploration.

So how Hardy written specific in general, connected the fate of the hero with the fate of mankind together? It is evidently from his creative novel intent. "Novels secret is letting an extraordinary thing has eternal and general sense", and art produced from the customs, local events and immutable things link, because they are portray of life, the authors should "express the eternal feelings and their opinions." It is worth noting that, in Hardy's creation, he used series of sill to summarize specific things, so that it has universal significance, in order to show that his work is to explore the destiny of mankind, rather than confined to Wessex aspirations of men and women which end of the tragedy. Despite his Wessex solitude, in a way very narrow, but Hardy tries to compile the figures venues in a wider geographical and historical scenarios long beyond this limit, with the words of Thomas Hardy that is to "look at the overall situation from the section."

First of all, Hardy placed the hero's activities in Auden wasteland which "Heaven" as "tent" and "irrigation grass" as "ground floor". Auden is not only a vast wasteland, but also a long history which has a profound symbolic meaning. Although it coldly observed many times "dumping", which is still eternal predicament. It symbolizes a possible world full of tragedy, people in this world alone, people's ideal can not be achieved, it is a symbol of mankind's uncertain future, it is also a symbol of hardships of the world road, which bring out the human insignificance and life short, it showed such a thought: In this cold world, how insignificant of human existence, people's wishes, feelings and creative spirit is just how absurd. This place has a vast area of the figure, there is a long history of writing style natural environment, and so Hardy out of the local color writer, too, adds to his Wessex universal significance.

Secondly, as the time handling, Hardy has not confined the middle and late of nineteenth century. His tragic story novels tend to play down the concept of time. His focus is not a specific time, specific location to a specific event, but to describe endure tremendous pain of modern civilization in the process of human development. In the "Return of the Native", Hardy repeatedly describe the human emotional changes in the external world changes, in order to write the history of change and development of the human mind:" Now barely tolerate life as something unlike in ancient times as a warm up for civilized life, "" the whole of nature in the future one day, only Aboriginal secluded wilderness as pale minimalist extraordinary place, in order to more ideas and feelings of those who absolutely harmonious, that Even when the species has not really come, but it also does not seem very far away. "

Such a description is not limited to "Return of the Native ", in other tragedies novels, Hardy also put humans in the past, present and future as a sharp contrast, in order to show that, in ancient times, people lived in a relatively simple and joyful environment, they are with nature, enjoying the blessings of nature. With the progress of human civilization, people are increasingly losing touch with nature. There are many scenes in their homes, "Tess" and "Jude the Obscure", 
this natural situation from contact to the human mind has brought such a big injury. It's not a wonderful future picturesque, Hardy seems, the human spirit in the world will be a wasteland, which is just match Eliot's Wasteland. Of course, Hardy's exploration of human destiny is not limited to the description of the scene; use the scene to express feeling, more through the hero's behaviors, mental activity to the performance psychological trauma that modern civilization bring. Hardy's tragic hero has a profound understanding of life, and they often feel the cruelty of life that produces pessimistic mood. Sometimes the character itself is a symbol of the trauma of the human mind. In "Jude the Obscure", the little time old man can said to be "modern pessimistic outlook on life," pioneer, is the aura of "unwilling to living" thought. He is in harmony with desolate wilderness, melancholy atmosphere.

Through the handing beyond time and space and the description of the hero life experience, Hardy enlarged the novel's capacity. We feel that Hardy's novel is not just an era, a local tragedy, but the entire world and human development of elegy. But on the other hand, the anomaly of this kind of social phenomenon attributed to the inherent tendency of the world, corresponding weakening the social criticism of his work, and covered the work with fatalism and pessimism colors.

\section{V. . CONCLUSIONS}

Through the suffering and fate of human, Hardy pointed rigid religious dogma, doctrine banal, which did not save people, but bring disaster. It does not derive spiritual comfort and tranquility, like Shu, "since her leaving his arms, they never get peace, and she never giving up until she died like him now!" People do not see religion maintain society and social cohesion, but we can see in the" Tess "and" Jude the Obscure" the religion is man spilt with himself, and even people with the nature of his own division. In summary, these two works by Thomas Hardy in character "deviant" behavior reflected the religious view from doubt God to criticize the reality, religious conservatives also revealed the hypocrisy of morality, religion pursuit of human trampling on freedom, religion used by alienated power, the evil side of human nature cause alienation, thereby religion sharply oppose with people. This is a level man divide with religion, and highlights one of modernist literature thought to express.

\section{References}

[1] He Yamin. From "Tess" and "Jude the Obscure" Look at Hardy's Modernist Literary Spirit [D]. Zhejiang University, 2011.

[2] He Yamin. From the Split of Human and Moral "Tess" and "Jude the Obscure" Modernist Literary Thought [J] exam Weekly, 2011,44: 2628.

[3] He Yamin. "Tess" and "Jude the Obscure" on the Present Research [J] Tongling Vocational and Technical College, 2011,02: 34-36.

[4] He Yamin. Of "Tess" and "Jude the Obscure" Human and Religious Divisions [J] World Education Information, 2012, Z1: 143-145.

[5] Yan Xuejun. Modern Spirit of Hardy's Tragic Novel [J] Henan Normal University (Philosophy and Social Sciences), 1989,03: 51-55. 